\title{
'n Baldadige rit saam met Pieter Fourie se Gert Garries
}

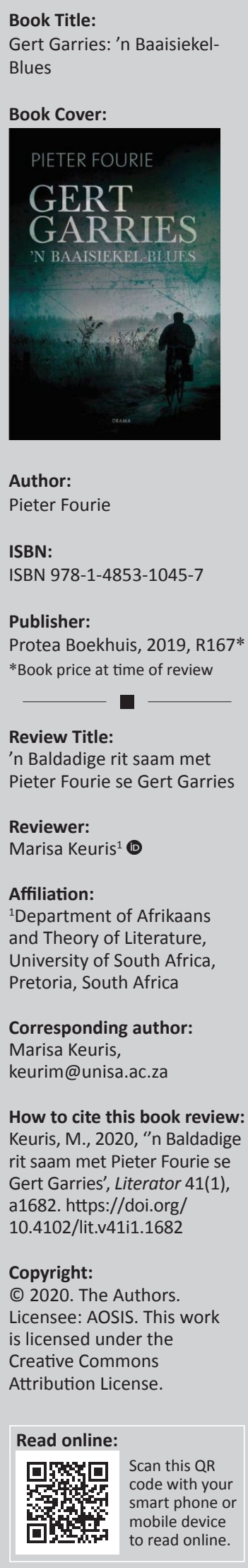

Pieter Fourie beskryf in 'n kort bedanking aan sy vriend 'Stephen' sy drama as "n baldadige reaksie' op Etienne Leroux se bekende roman, Magersfontein, o Magersfontein! In haar bespreking van die drama wys Dorothea van Zyl (2004:121) daarop dat die Gert Garries-karakter reeds voorgangers in ander Leroux-werke gehad het (o.a. Isis Isis Isis en Onse Hymie), terwyl sy ook aantoon in watter mate Fourie gebly het by Leroux se uitbeelding van Gert Garries en Le Grange (bl. 124-127).

In Leroux se roman is die spietkop Le Grange en die plaaswerker Gert Garries randfigure, wat Pieter Fourie in sy drama oorneem om as hoofkarakters in hierdie eenbedryf te figureer. Gert Garries se drie dae lange fietsrit met die lykie van sy kind by hom, sy burokratiese stryd om toestemming te kry om die lykie te begrawe en die kruising van sy pad met dié van Le Grange en die daaropvolgende absurde gebeure by Magersfontein met ' $n$ filmspan, vorm die dramatiese inhoud van hierdie drama.

Volgens Fourie is sy verdere ontginning van Leroux se twee karakters gedoen met die aanmoediging en seënwense van Leroux self. Fourie verwys ook na 'n soortgelyke bekende voorbeeld in die dramaliteratuur waarin so 'n aanpassing gedoen is, naamlik Tom Stoppard se oorname van twee randfigure uit Shakespeare se Hamlet in sy drama, Rozencrantz and Guildenstern are dead.

Gert Garries (voorheen met die subtitel: 'n Baaisiekel-babelas) is deur Fourie vir die Klein Karoo Nasionale Kunstefees geskryf en het op 30 Maart 2002 (onder regie van Marthinus Basson en Rooderandt Produksies) suksesvol gepremière. Die stuk is daarna ook opgevoer by Kunstekaap, in Bloemfontein, by Aardklop en by die Walvisfees op Hermanus, en is gunstig deur gehore ontvang. ' $n$ Radioverwerking van die drama is deur Eben Cruywagen in 2019 gedoen en kan op RSGplus geluister word: (https://rsgplus.org/vermaak/radiodrama/verwerking-van-m/).

Protea Boekhuis se publikasie van die drama in 2019 gee 'n nuwe subtitel aan die drama, naamlik 'n Baaisiekel-blues. Hoewel die vorige subtitel se verwysing na babelas sekerlik ook 'n heel gepaste een is, aangesien drank en dronkwees veral by Gert Garries 'n groot rol speel, is die verandering na blues ryker aan assosiatiewe krag. Die onderliggende patos van die dramatiese gebeure word dus reeds in die titel op die voorgrond geplaas.

Die gebeure is in 1975 geplaas - dus in 'n tydvak waarin die apartheidsideologie van die Nasionale Party hoogty gevier het. In talle van Fourie se dramas beeld hy die rassisme inherent aan hierdie ideologie uit - dikwels op skryende wyse soos in Die koggelaar en Ek, Anna van Wyk-maar dit is veral in hierdie drama waarin die absurditeite en ironieë van hierdie politieke bedeling in oortreffende wyse uitgebeeld word. Die lesers en toeskouers weet dikwels nie of hulle moet lag of huil terwyl Gert Garries (en sy dooie kind) die slagoffer is van 'n absurde burokrasie nie.

Gert Garries op sy baaisiekel se pad kruis met dié van 'n spietkop, Le Grange, ingenome met sy nuwe uniform ('n replika van die uniforms wat die Nazi SA of Sturmabteilung gedra het!) en die ontmoeting vind binne 'n verwagte baas-klaas-atmosfeer plaas. Hoewel Le Grange as wetstoepasser van die ou bedeling grotendeels as 'n komieklike karakter vol eiewaan uitgebeeld word, as iemand wat meestal situasies heeltemal misverstaan (o.a. die skreeusnaakse 'amptelike' begeleiding vir die filmgroep wat na Magersfontein reis), toon hy verbasende simpatie met Gert Garries se situasie en die eksistensiële absurditeit waarin hy hom met sy dooie kind bevind. Hierdie simpatie vind 'n hoogtepunt in die eindtoneel waar hy nie net die begrafnis van die lykie bywoon nie, maar selfs ook die blomme wat hy bymekaargemaak het vir die skoonheidskoninginne van die filmgeselskap, op die graffie pak. In hierdie toneel - ook vol swart humor - is dit nie net Gert Garries se uiteindelik verset teen die stelsel nie (hy begrawe sy kind sonder toestemming in 'n historiese begraafplaas waar dooie soldate van die Magersfonteinveldslag begrawe is, d.w.s. ' $n$ 'blanke' begraafplaas), maar is dit ook Le Grange se nuwe insig in die onmenslikheid van die 
apartheidsideologie en sy empatie met die lotgevalle van Gert Garries en sy dooie kind, wat 'n mens bybly.

Gert Garries: 'n Baaisiekel-blues is 'n uitsonderlike drama in Pieter Fourie se oeuvre: saam met Gert gaan die lesers en toeskouer op 'n dolle reis vol swart humor, skreiende ironieë en klugtige absurditeite, maar besef ook ten slotte hoeveel patos daar in die lewe en dood van 'n enkele baba opgesluit kan lê. Fourie is bekend vir sy uitsonderlike karakterbeeldings (veral in sy sogenaamde volksdramas, byvoorbeeld die Faandramas) en dialoog vol oorspronklike beeldspraak. In hierdie drama sou net die besondere taalgebruik (vergelyk die gesprekke tussen Gert en Lord Sudden, asook sy interaksies met die swart chauffeur) 'n studie op sigself kon inhou. Die publikasie van hierdie drama deur Protea Boekhuis word dus verwelkom: dié werk van Pieter Fourie kan as een van die hoogtepunte in sy oeuvre beskou word.

\section{Literatuurverwysings}

Van Zyl, D., 2004, Gert Garries, die nimlike hy: Die konstruksie van die ander in 'Magersfontein, o Magersfontein!' deur Etienne Leroux en 'Gert Garries, 'n baaisiekel babelas' deur Pieter Fourie, Stilet 16(1), Maart, 117-129. 